\title{
Adaptation Strategy of Batak Toba Ethnic in Alas Land (a Case Study on Terutung Mbelang Village, Kutacane)
}

\author{
Agnes NoviantiPermata Sari Hutahaean, ${ }^{1}$ Usman Pelly, ${ }^{2}$ IchwanAzhari, ${ }^{3}$ \\ Social Anthropology at State University of Medan \\ Medan, North Sumatera, Indonesia \\ agnesnoviantihutahaean@yahoo.com
}

\begin{abstract}
The aims of this study is to describe the adaptation strategy done by Batak Toba ethnic who moved to Alas Land. This study uses qualitative research design with anethnographic approach. The technique of data collection was taken by deep interview, observing the community participation, and study of literature. Informants were selected by using purposive samplings, such as village chief, Batak Toba figure who know the history of the village and the people who moved and lives at TerutungMbelang village, Kutacane. Data were analyzed by theethnographic approach. The finding shows that Batak Toba ethnic moved to Alas Land for getting prosperity of life that they did not get on their land, Batak Toba ethnic got information about Alas Land from road laborers who built roads from Sidikalang to Alas Land. The adaptation strategy was making anarea or village for Batak Toba ethnic called pupa (Capsule) as the ethnic fortress, as farmers Batak Toba ethnic shared the information and knowledge about farming rice to Alas ethnic, taught thealphabet and helped Alas ethnic to think ahead. Batak Toba ethnic built church on Batak Toba ethnic settlement as the symbol that shown Batak Toba ethnic area.The obstacles happened when Alas ethnic had been jealous upon the success of Batak Toba ethnic in their Land. Then, wanted to chase away Batak Toba ethnic. The conflict was solved by holding deliberation and consensus led by theregent and thevillage chief.
\end{abstract}

Keywords: Migration, Adaptation Strategy, Batak Toba ethnic

\section{INTRODUCTION}

Batak Toba ethnic has basic life by moving from one place to another for maintaining their life and their complex self-esteem,to be number one. Batak Toba ethnic also has cultural missions for expanding their territorial and establishing akingdom in the new place. Every decision to move is influenced by the cultural mission of each ethnic group. By looking at the cultural missions that have been brought by the immigrants to the other place, we can see how the adaptation process of the dominant host place faced the new concept culture from the migrants and the way the immigrants retain their ethnic and cultural identity on the overseas. The immigrants have to be able to sustain their life in the area that they attend so they can survive by adapting to the environment,society and the social condition of that area.

This study discusses how the Batak Toba ethnic adapted their life with Alas people at TerutungMbelang village, Kutacane as the new area for them. Batak Toba ethnic came to Alas Land for seeking the prosperity life that they did not get on their land. Besides that, they also hold their philosophy principles of Hamoraon (wealth and prosperity), Hagabeon(many descendants), and Hasangapon (honor) that encourage them out of their homeland. To be able to settle in Alas Land, the Toba Batak ethnic group must adopt an adaptation strategy so that they can be accepted by the ethnic host (Alas ethnic group). The strategy must be done because of cultural and religious differences that can create a dispute. In addition, Alas ethnic groups are also less accepting of other ethnic groups to use the land in the village because they think that their land should be controlled by the ethnic host and not the ethnic immigrants.

According to Whitten and Whitten: (1972), Graves and Graves: (1974), and Berger: (1976) (in Pelly, 2013: 99) adaptation strategies are the ways in which foreign travelers work to overcome the obstacles they face and to obtain a positive balance with the background conditions of the nomads. In this case, it can be seen from the ethnic settlement which where a village is a group of houses from the settlement of the nomads. In this residential group, the traditional social relations and social activities of ethnic groups from their hometowns will be retained, 
such as life cycle rituals, cultural performances are held and their respective regional languages are spoken in daily conversations. Members of each ethnic group within the village tend to have similar occupations. In this case, ethnic settlements as an adaptation strategy that retains ethnic immigrants to live in the area as they feel their own home in the overseas lands through their daily interaction activities.

Pelly (2016: 13) also stated that adaptation strategy can be done with theexchange of technology where the arrival of migrants as acomplement to the area they come to by sharing knowledge between ethnic immigrants with theethnic host.

Hasselgren (2008: 132-133) explains that the adaptation strategy of ethnic Batak Toba groups uses ethnoreligious identity because ethnic identity and religious identity are closely related. The ethnic Toba groups are active in shaping and accommodating Christianity in their view of ethnoreligious identity, as ethnic identity and religious identity are closely related. Toba ethnic groups are active in shaping and accommodating Christian teachings into their view so that where there is a Batak Toba village there is a church building that stands adjacent to the settlement. Cunningham (1958: 93) argues that the new territory that the ethnic Batak Toba occupy will become a new empire for them so that the Batak Toba ethnic groups signal that the area is inhabited by their group by setting up villages as well as maintaining pets such as dogs and pigs that can limit they are with another ethnicity because the pet is disliked by other ethnic groups.

Nainggolan (2006: 86) emphasizes the Toba Batak adaptation strategy using identity change. Toba Batak migrants must adapt to the identity of the area they are visiting. The new situation faced by migrants brings about a change in their attitude, which is where identity changes occur through interactions and cultural transactions between Batak Toba ethnic groups and other ethnic groups. These interactions and transactions exist because migrants should choose their orientation and strategy to live together with other ethnic groups. From the decomposition of adaptation strategy above, it can be said that the immigrant community will always adapt their strategy in maintaining their life by studying their new life, that is interacting with local people either with their culture or host culture so that adaptation strategy process can be done through the mixing process.

\section{METHOD}

The research design is qualitative with anethnographic approach. The technique of data collection was conducted through in-depth interviews, participant observation, and literature study. The informants were chosen purposively with the criteria of village chief, Batak Toba figure who know the history of the village, and the people who moved and lives at TerutungMbelang village, Kutacane. The data were analyzed ethnographically.

\section{RESULTS}

The causes of Batak Toba Ethnic Migration to Alas Land

Since 1930. Batak Toba ethnic group started their migration to the area outside Lake Toba because they wanted to find fertile ground to meet their needs. Samosir Island is located in the middle of Lake Toba, including one of the driest areas in Sumatra because the land is hilly and the trees are rarely growing up there. Then, the erosion is quite high in this area. The mountainous and heavily subsisting terrain causes many obstacles in the development of agricultural enterprises such as agricultural expansion, while for the expansion of residential areas it is also difficult to build roads and irrigation facilities. The Tapanuli area is less fertile and unfavorable, thus causing negative impacts on agricultural land and ultimately encouraging farmers to move and seek better areas.

In 1930, 30.000 people of Batak Toba ethnic group went to Pematangsiantar, Batak Simalungun area and in 1950-1959, Batak Toba began to migrate from their area to East Sumatra as many as 250.000 . The Migration has existed 
long before the migration group mentioned above. Only at that time were not at once as many as above and the destination of their migration areas were other Batak sub-tribes, such as Dairi and Alas to the North and Silindung, Angkola and Asahan in the South (Cuninggham 1958: 82-87).

As noted above that ethnic Batak Toba groups have migrated to new areas including the Alas land area through the opening of the road from Sidikalang to Tanah Alas due to their own willingness without coercion to seek prosperity that cannot be obtained from their own villages and create new land or new settlements for expanding the Batak empire. Alas Land is a destination for ethnic Batak Toba migrants because it has such a fertile soil, the land is still empty so it is possible for migrants to open village.

TerutungMbelang Village is a division of BungaMelur village established in 1916, the village was first occupied by ethnic Batak Toba group called Siregar because the opening of his family is Siregar clan and the first village Geuchik(village chief) is the first person to open the Huta is BilmarSiregar.

The first ethnic group of Batak Toba in Kutacane is the village of Rantau Dior, it is said the village of Rantau Dior because the Batak Toba people come to Alas area is known as the slogan MarantauorTusi, Dior-diorama (wanderers come here to search) search here referred to is looking for land and friends to establish the village.

Batak Toba ethnic groups get land and make village by permission of King BintangSilean. The village is a land granted by the kingdom (Keujeuruen). The Silean clan in Alas ethnic is similar to the Siregar clan in ethnic Batak Toba or it can be said that one of the descendants of King Bintang grants this land through Keujeuruen (kingdom) Babel by granting a permit to reside in Alas land without being subject to customary money. King Bintang asked the ethnic Toba Batak farmers to make good land and want to teach ethnic Alas in cultivation, other than that Tanah Alas land used to be a little populated and forested so that the King of Stars willing to give the land for the area to be crowded. After the settlement of the migrants, Batak Toba ethnic group withdraw their brothers from Samosir to go to Tanah Alas.

\section{Adaptation strategy of Batak Toba ethnic group}

The Batak Toba ethnic group became one of their strategies to settle in Tanah Alas because their village is an ethnic fortress that can protect them from other ethnic disturbances. Village (Huta) as the pupa or capsule used by Batak Toba ethnic group as a fortress, which was every society mutually reinforces each other. The village also can reduce the longing ethnic Batak Toba ethnic groups in their hometown because the daily pattern in the hometown is almost the same as the pattern of daily life of anethnic group of Batak Toba in Tanah Alas.

In the village TerutungMbelangKutacane still apply the customs and customs of ethnic groups Batak Toba where they are still using the local language in communicating the Batak Toba language from children to adults all passively use the Batak Toba language, but if outside they use the Indonesian language in interacting with outsiders. Batak Toba customs are carried out by ethnic Batak Toba groups in Tanah Alas, where customary ceremonies in the other place can be regarded as an opportunity to refresh their primordial loyalty to their hometown; they can enjoy the splendor of their noble culture even though it is far apart physically from the cultural center in their hometown.

The village is also an ethnic citadel where ethnic Batak Toba groups are free to keep pets, they keep dogs, pigs, and buffaloes for their needs, they can be a defense for them where Alas ethnic groups do not want to enter Batak Toba ethnic village because animals Their pets such as dogs and pigs are regarded as animals that are defined for the Moslem.

The next strategy is the process of exchange of technology occurred in the village where the Alas ethnic group is a reliable fish farmers in making ponds and maintain fish are transmigrants ethnic Batak Toba group is rice 
farmers. Alas ethnic group has less knowledge in rice field while ethnic Toba Batak less knowledge to cultivate fish well. The Alas ethnic group saw the arrival of ethnic Batak Toba groups as a complement to their agricultural life. They need Batak Toba ethnic group to gain new skills as a paddy farmer, Alas ethnic groups always pay attention to how the Batak Toba farmers work in the rice fields and imitate so that eventually the Alas ethnic groups know how to plant rice well otherwise Batak Toba ethnic gain knowledge in learning how to create a good pond and how to cultivate fish from the Alas ethnic group, and can live in the area. Both see complementary positions in the process of sharing their knowledge.

Batak Toba ethnic group also introduced letters to Alas ethnic groups who could not read and write, at that time the knowledge of ethnic Batak Toba was better than the knowledge of ethnic Alas, knowledge of ethnic Batak Toba group obtained from the Dutch side who at that time came to the Batak land for evangelistic mission of Christian spread and colonialism. Batak Toba ethnic groups also shared knowledge in managing the village.

The church also has been influenced by adaptation strategy of Batak Toba ethnic group, In TerutungMbelangKutacane stands church of GKPI LawePasir indicating that the settlement is Batak Toba, theethnic group. In addition to the church GKPI, there is also HKBP BungaMelur church is the church that first stood in the village. The Batak Toba ethnic group built a church in the Batak Toba migrant residential area not only as a place of worship but the church building can be regarded as a symbol indicating ethnic Batak Toba group has set a new kingdom in their residence area.

Barriers to the Toba Batak Ethnic Group in Tanah Alas

The process of breeding ethnic Batak Toba does not always run smoothly, there must be rejection of the host population who saw the success of immigrant residents who live in their land, the rejection triggered the conflict that was the occurrence of disputes between the two ethnics, which occurred between the years 19751981, for six years.

Conflicts that occurred due to the emergence of heartache, jealousy and the misunderstanding of the two ethnic, this triggered a dispute that had been felt by the two ethnic groups, namely ethnic groups Alas and ethnic groups Batak Toba. The dispute started because of the jealousy of the Alas ethnic group for the success of the Batak Toba farmers in Alas Land. In terms of material, ethnic farmers Batak Toba ethnic group more advanced at that time compared with Alas ethnic groups due to the hard work of those who farm. At that time knowledge of Alas, ethnic cultivation was still minimal and their knowledge is still low compared to the knowledge of ethnic groups Batak Toba farmers faster than Alas farmers, seeing the condition Alas ethnic groups felt jealous and wanted to revolt their land and they must be more successful compared to the group of immigrants. From the Alas ethnic rebellion, there was an interaction split between ethnic groups Alas and ethnic groups Batak Toba so that interaction was not good to happen.

Disputes often occurred in the afternoon when there were still many Toba Batak farmers who were in their fields, when the Alas ethnic groups wanted to invade the village, the young ethnic Batak Toba who walked around the village will ring a bamboo hanging in their homes, each resident as a code that the Alas ethnic group came to attack the Batak Toba village, family members who were at home will call their relatives who still worked in the fields through the back door of the house where the average of their rice fields are behind their homes so that farmers who still working in the fields could hear voices or shout and immediately ran to return to the village to help his village friends in the face of Alas ethnic groups.

Conflict often occurs around the road to the village and the road to the fields, never the Alas ethnic group to the village because the youths who guard around the village always give a sign by ringing bamboo while shouting 
"Nungaorhallaki" (they have come) to all their compatriots, they signaled when Alas's ethnic group had been seen from a far to come to the village so that all the villagers were preparing to protect their village by blocking Alas's ethnic group into the township.

The tools used by Toba Batak ethnic groups in protecting their group from the Alas ethnic group are ambalangand hujur. Grasshopper is a kind of traditional weapon made of pokki leather strap in use for rock throwing swings and lucky is a spear which is made of wood and iron-filled ends of women and children hiding in the house and in the church holding ground-milled peppers and mixed with sand so when they approached, the chilli spice was thrown into the face of the Alas ethnic group who approached them. Alas used by ethnic groups in facing ethnic Batak Toba ethnic groups are knives and machetes. The ongoing warfare did not result in casualties but many were hit by stone throws and sharp weapons.

During the conflict period, ethnic Batak Toba group came out to the market and their school had to be accompanied by the security personnel, the police, so that the fighting did not happen in the general area. The settlement of the conflict between ethnic Batak Toba and Alas ethnic groups was solved by deliberation and consensus led by Regent T. DjohanSyahbudin, SH and village head of the two ethnic groups and witnessed by Alas ethnic group and ethnic group of Batak Toba.

But now the life between Batak Toba ethnic group and Alas ethnic group goes well, good social interaction occurs, social interaction is realized through the activities of association organization and eliminates the egocentric nature so that there is no social distance in society, thus the interaction process can run well. Now that Alass younger group is already more advanced and tenacious in their own land, their rice cultivation system has advanced and they are willing to work hard in living their families, they are now willing to wander to get decent jobs and higher education to other areas, in the past ethnic Alas, refuses to get out of their land.

\section{CONCLUSION}

1. The process of migration of Batak Toba ethnic groups to Tanah Alas occurred due to the basic needs of the economy and the desire to have a more prosperous life. Most of the immigrants who come to Tanah Alas did not feel a decent life in their land, so they were looking for new land and new areas to improve their living economy. In addition, within the Batak Toba ethnic group migration is a cultural encouragement in which migration can expand their territory as a cultural mission of the ethnic Batak Toba group that is to establish anew kingdom. The Batak Toba ethnic group came to the Kutacane area with the opening of the road from Sidikalang to Tanah Alas (1909-1914). This was a source of information for ethnic Toba Batak groups who come later on. News about Alas Land was getting widespread among the Batak Toba farmers and they wanted to enter the fertile Alas Land.

2. The process of adaptation strategy of Batak Toba ethnic group in Tanah Alas is done by (1) making settlements or villages (huta) as pupa (capsule) which they use as ethnical fortress, (2) exchange of technology where group farmers ethnic Batak Toba teaches the knowledge of rice farming and ethnic groups Alas shares knowledge on how to make ponds and cultivate fish (3) Batak Toba ethnic immigrants share knowledge with Alas ethnic so Alas ethnic groups can think more advanced, such as how they dress up more politely, arranging the village by building houses together, and introducing letters or early education to Alas ethnic groups, all knowledge of Batak Toba ethnic groups was obtained from Dutch people who came to Batak Land with colonizing mission and evangelistic mission in spreading Christianity (4) Batak Toba ethnic groups also built churches in area the Batak Toba migrant temple so that the church building as a 
symbol shows the ethnic Batak Toba ethnic groups have established a new kingdom on their residence area.

3. Constraints that occur was the conflict between ethnic groups Batak Toba and ethnic Alas due to the envy felt by ethnic Alas for the success of the ethnic Batak Toba in their land through agricultural products and rumors heard by the ethnic Batak Toba that ethnic Alas want to take agricultural products and plantations without getting permission from Toba Batak communities, Toba Batak conflict with Alas occurred approximately six years. This conflict was solved by holding deliberation and consensus led by regent and the village leader

\section{REFERENCES}

[1] Cunningham, Clark E. 1958. The Postwar Migration Of The Toba Bataks To East Sumatra. New Haven: Yale University. (Southeast Asian Studies)

[2] Hasselgren, Johan. 2008. Rural Batak Kings in Medan: The Development of Toba Batak ethnicReligious Identity in Medan, Indonesia, 19121965). Medan: Bina Media Perintis.

[3] Nainggolan, Togar. 2006. Batak Toba in Jakarta. Medan: Bina Media.

[4] Pelly, Usman. 2013. Urban Migration and Adaptation in Indonesia: A Case Study of Minangkabau and MandailingBatak Migrants in Medan, North Sumatra. Medan: UNIMED Press.

[5].- 2016. Ethnicity in Multicultural Politics Book II. Medan: Casa Mesra Publisher 